\title{
A north for Brazilian integration in the international sustainable development
}

\section{Short communication}

The mentions reported in this essay relate to the experience of a Brazilian in Sweden for 40 days that he was at SLU. The initial idea was to prepare a note on the European Union's International Forestry Policy in the framework of the European Union (EU) integration negotiations. However, from the perspective of a person who develops his academic and professional activities in Brazil, it was decided to establish relations between these different realities, that is, Brazil and the EU, two regions with continental territories, but with different historical, cultural, economic, climatic and environmental issues. The first analysis was that EU countries are making a major effort to reconcile environmental and forest agendas with the aim of integrating different visions and economic interests related to sustainable development in the forest sector. ${ }^{1,2}$ They are two aspects that go together, but they have different agendas. The first interest, the commercial, aims to reduce barriers between countries and so that the products of wood produced in the European continent can circulate and favor the generation of jobs and income. Although it is considered to be the main mission of the European Union, however, it seems that governments are also positioning themselves truly concerned about climate change, caused by industrial pollution. And in this way, they are especially provoked by the political action of the United Nations, extrapolating the issues of the productive sectors, with social and environmental concerns, making the corporations adapt to the demands of sustainable development and to increase their ecological footprint by reducing their emissions and environmental impacts and improving their processes with sustainable technologies.

Some information needs to be kept in mind to make a comparison about the reality of Europe and the new world represented by the Brazilian case. Being a country with different regions and each with completely different realities, Brazil's social development process culminated in the consolidation of a very centralized political system in the capital of the Republic, in Brasilia. Comparatively, it is as if the national government was equivalent to the $\mathrm{EU}$ and the states of the federation were equivalent to the European countries. For all this, the vision of sustainability that the EU and the UN wish to plan in the old world, is already consolidated in Brazil, because with regard to environmental policies, the federal Constitution already imposes a hierarchical system, greatly restricting the power to decentralize environmental policies. In fact, for example, the federal Atlantic Forest Law, published in 2006, allowed in a little over ten years the increase of the natural areas of this still threatened biome, which at the end of the 20th century had less than $7 \%$ remaining original forests. Regarding sectoral policies, it is worth mentioning historically that the implantation of the forest sector in Brazil occurred since the 1960 's, with the creation of the first's forestry engineering schools, together with the publication of the forest code, as well as with the implementation of fiscal incentive policies for forest plantations. ${ }^{3}$ This policy lasted until the early $1980^{\prime}$ 's, and allowed to consolidate in Brazil, a forestry sector that today depends little on public power. These companies settled in regions with a forestry profile, did not compete with the agricultural sector, and returned their production to the domestic supply and export. It is worth mentioning that the Brazilian forestry sector is responsible for about $6 \%$ of the
Volume 8 Issue 2 - 2018

\author{
Alvaro Boson de Castro Faria \\ Forestry Engineer, Federal Technological University of Paraná, \\ Brazil
}

\begin{abstract}
Correspondence: Alvaro Boson de Castro Faria, Forestry Engineer,Adjunct Professor of Forestry Engineering at the Federal Technological University of Paraná, Brazil UTFPR; Road to Boa Esperança km4 s/n, CEP: 85660-000, Dois Vizinhos, Paraná, Brazil, Email alvarob@utfpr.edu.br
\end{abstract}

Received: November 29, 2017 | Published: April 25, 2018

Brazilian GDP, with the great majority of companies that have forest certification. ${ }^{4}$ It was important to note that the pressure that the United Nations is exerting to make the Millennium goals in Europe apply is as effective as the pressure that the international community also exerts in Brazil. This demonstrates the seriousness with which the EU is dealing with sustainable development. This is because, from the point of view of a Brazilian citizen, there will always be a lot of mistrust about the good intentions of the public power, both locally, nationally and internationally. This mistrust finds justification in a society still quite unequal and where corruption has become the general rule. The origin of this process is still rooted in the military coup of 1889 , which overthrew the parliamentary monarchy and which had promoted much social development since Independence in 1822 and which, in the nineteenth century, implemented reforms for the gradual extinction of slavery. Thus, the sad truth is that the presidential republic founded in Brazil was not created to serve the general and public interest, but rather the interests of segments of political coalitions and social groups that felt hurt by the end of slavery and felt in the right of stealing society permanently, not having been compensated with the liberation of the slaves. ${ }^{5}$ Analyzing the other side of reality, the Brazilian republic established a secular state and, over time, consolidated a society quite liberal in customs. This transformation took place naturally, and it was a social effect that contrasted with the Catholic conservatism that existed at the time of the monarchy, and helped to consolidate the new republican regime. This is why the experience in Sweden was very valid, since it allowed us to verify how a monarchic and free society behaves, but based on doctrines influenced by another aspect of Christianity, that is, Protestantism and that allowed the development of a freedom of expression with very different motivations from the Brazilian case. The concept of equality and its different facets is widely respected in Europe and tends to consolidate in countries that recognize its importance. In Brazil, shaped by the centralization of customs, the leaderships of left and right social groups strive to protect hierarchies of power. In the case of the right, these groups accuse the cultural Marxists of using the social equality and sustainable development agenda to implement frightening communism in Brazil. That's a justification for, a significant part of the right tends not to recognize the importance of sustainable development. On the other hand, with the decline of the Workers' Party and the fall of President Dilma Rousseff in 2015, together with the eminent and probable arrest of former President Lula for corruption scandals, convicted in higher 
courts, consolidated the crisis of the Brazilian left. In practice, what has been seen in Brazil is the emergence of a right that values moderate Christian conservatism in secularism, social welfare and economic liberalism, led by parliamentary populist political leaders linked to the army and the evangelical church. In addition, the recent rise of another type of right, based on Catholicism, led by members of the Brazilian royal family, but still outside the political establishment, was verified.

It is questioned whether the restoration of the parliamentary monarchy could be good for Brazil, considering its vertiginous increase in social networks and alternative media, from 2013, when the streets were taken by the citizens indignant with the systemic corruption of the republican model. In a first analysis, it would be positive, since giving voice to these segments could favor the reflection and the connection of the people with a historical past in which the members of the elites gave good examples of meritocracy and where the Emperor Dom Pedro II inspired the best feelings of public interest. Although until recently the population was accustomed to pay attention only to the stars of football, music and carnival, the fact is that such collective catharsis was verified in Brazilian society, given the freedom of the press and the success of anti-corruption operations, which showed promising results for raising awareness of the population in general and the maturing of democracy. The great virtue of this new right is to defend the cause of social justice and the fight against corruption. On the other hand, a real concern for those who want to defend sustainable development is that, over time, the acquisition of this new right may result in crises stemming from economic liberalism, seen in the distant past and more specifically related to the environmental crisis than in Brazil is strongly summarized by increased deforestation of native forests. One of the great achievements of the Brazilian Federal Constitution of 1988-a charter that guarantees several social rights - was the objective recognition of the commitments signed internationally in the sustainability agenda, and the repeal of this achievement would be a great loss for society. What is striking about the Brazilian reality, in fact, is to verify in the law that, on the one hand, the republican conservatism preaches the inequality between the classes with a mixture of state capitalism with the liberalizing slopes.

On the other hand, mention should be made of the Catholic conservatism of Dom Bertrand de Orleans and Braganza (of the monarchical succession), which was directly against the commitments of sustainability (having even published a book criticizing, see, ${ }^{6}$ in contrast to the recognition of the encyclical Laudato Si, by Pope Francisco. ${ }^{7}$ These findings are demonstrations that Brazilian society is still very resilient in accepting a paradigm that companies and governments, in pursuit of efficiency, cannot work together for socially uplifting goals. As a general result, it still exists in society, disbelief in the Welfare State, in the Environmental Economy ${ }^{8}$ and little concern to develop technological innovations, based on the gigantic natural wealth that it possesses. Currently in Brazil, there are two national policies that need integrated actions to achieve common goals. The first, enacted in 1981, concerns government command and control to monitor the environmental impacts of polluting activities and ratified the polluter pays principle. And the second, of 2012, deals with climate change, having legally recognized the principle of preventing impacts on climate change. Federal laws do not overlap in terms of power, and this analysis is important because the Brazilian Constitution of 1988, superior to the two public policies, presented the ecologically balanced defense of the environment as an important basis for sustainable development. The above arguments are relevant in the analysis of the REDD+ mechanism for Brazil, since the scientific environment currently tends to value more the effects of carbon sequestration by forests, even if the possible environmental impacts of this process could damage the balance of ecosystems. As an example, carbon sequestration by taquaras (a type of native bamboo) in mixed ombrophilous forests in the southern region interferes with local biodiversity. One tendency of countries financing REDD in developing countries is that projects must also combat poverty. ${ }^{9}$ In the case of Brazil, what is found as a positive resonance in this objective is forest certification, since forestry companies are widely located away from large urban centers. ${ }^{10}$ This is one of the few cases in Brazil, in which the productive sector does not conflict with the public power in the achievement of the Millennium goals. Finally, it was very important in the course, to understand a little more about the funds that are financing the REDD mechanism and, in Brazil, made available through BNDES intermediation, through the requests of the Amazon Fund. These features do not have to be returned, and show the noble face of countries that are really concerned about climate change. For all the arguments, Brazilian society needs to improve the efficiency of its State of Social and Environmental Welfare and disconnect itself from the paradigm of capitalism versus communism, thus recognizing other paths of social development, taking advantage of international opportunities and reflecting more on a world view that countries like Sweden, Norway, Finland, Germany and others have to teach.

\section{Acknowledgements}

None.

\section{Conflict of interest}

The authors declare there is no conflict of interest.

\section{References}

1. Pulzl H, Hogl K. Forest Governance in Europe. In: editors. European Forest Governance: issues at stake and the way forward. Finland: European Forest Institute; 2013. 102 p.

2. Winkel G, Sotirov M. Whose integration is this? European forestry policy between the gospel of coordination, institutional competition, and a new spirit of integration. Environment and Planning C: Politics and Space. 2014;34(3):496-514.

3. Faria $\mathrm{ABC}$. Environmental education policies for forest engineering teaching. Ambience. 2007;3:385-393.

4. Abraf, Mendes L. Brazilian forestry and timber yearbook. (Org.) São Paulo (Brazil): Gazeta Santa Cruz; 2016.

5. Faria ABC. Contemporary Republican Reflections: An Invitation to Reconciliation. Brazil: Prismas; 2016.

6. Bragança BO. Environmentalist psychosis: the backstage of ecoterrorism to implant an ecological, egalitarian and anti-Christian "religion". São Paulo, Brazil: Plinio Corrêa de Oliveira Institute; 2012.

7. Vieira FG. Encyclical Letter of Pope Francis: Laudato Yes-about the care of the common house. Cachoeira Paulista, Brazil: Canção Nova; 2016.

8. Constanza R. What is Ecological Economics ?. Ecological Economics. $1989 ; 1(1): 1-7$

9. Angelsen A, Brockhaus M, Sunderlin Wd, et al. Analysing REDD +: Chalenges and choices. Indonesia: Center for International Forestry Research; 2012. $456 \mathrm{p}$.

10. Borsato, Faria ABC. Forest certification as an instrument of corporate social responsibility. In: II Seminar on sustainability, Curitiba, Brazil: UNIFAE Centro Universitário Franciscano; 2007. 